\title{
Rhetorical Questions: What Google Couldn't Provide for Education
}

\author{
Herlina Suksmawati ${ }^{1}$, Praja Firdaus Nuryananda ${ }^{2}$ \\ ${ }^{1}$ Department of Communication Science, UPN "Veteran" Jawa Timur, Indonesia \\ ${ }^{2}$ Department of International Relations, UPN "Veteran" Jawa Timur, Indonesia \\ Corresponding Author’s Email : herlinasuksma@gmail.com
}

\begin{abstract}
We believe that education nowadays has been conducted differently both sides, for the subject and the object. The term "education" has been inherently related to moral obligation in studying and implicitly looking for answers to theoretical and practical problems in life. Meanwhile, current education has integrated to Internet of Things (IoT), and subsequently confirming the existence of Manuel Castells' "network society". This informational society thus undermines the epistemological mechanism in education. The word "googling", refers to searching with Google, has been so popular in education nowadays because Google often gives us answers to theoretical and practical problems in life, answers that should have been provided by education. Hence it becomes a valid common sense to think that Google almost provide us with all information they had inside the online network. Whilst technology always associated with double-edged sword to humanity, the use of Google has made younger generation become fragile in foundational thinking, as Rhenald Kasali called them "Strawberry Generation". But as Google gives society with abundant information, yet Google fails to deepen society knowledge and understanding things. Therefore, our hypothesis is what Google has failed to provide the society is rhetorical questions. With the internet, everyone could make their own fabricated "truth", but ironically people sometimes fail to understand the knowledge itself. This paper propose the idea of "rhetorical question" that vital in knowledge, has failed to be provided by internet. In sum, "rhetorical question" would be a good instrument to counter "Google mechanism" to make education better.
\end{abstract}

Keywords: network society, education, Google, rhetorical questions

\section{INTRODUCTION}

There is one big complaint in the Indonesian education industry today regarding the characteristics of the object of education, namely students. One major complaint criticizes the current character of students who are often undisciplined, unable to focus on studying for a long time, and less active in psychomotor activities both inside school and outside of school. This is especially true of many teachers, both in primary, secondary and higher education. This 
complaint is often identified as a problem of contemporary education. This educational problem is often described as a negative relationship between technology and humans now, or gadgets with students. There is an assumption, that the device is the cause of students becoming passive mentality. ${ }^{1}$

There is even a tendency that students can now easily find teachers' substitutes through devices. Of course if the teacher's role is replaced only to find out the meaning of a word and a little explanation about it. But it should be noted that the changing role of the teacher by the device or even by Google is something that is likely to be inevitable as technology advances. If the method of learning and teaching process in school/college classrooms does not change more sophisticated, then it could happen. Now there is even more and more promotion of e-learning (electronic learning) that does not require face to face in the classroom and only based on assignments. ${ }^{2}$

But is it true that technology only brings negative impacts? Of course not. The thing to remember is that the majority of students today are those who were born in the digital age, or what has become popularly referred to as digital native. It is different from twenty or thirty years ago with a conventional mindset of education and everything is done manually. The pattern of teaching is still oneway, from teacher to student. Whereas now even the teaching pattern is not only two-way, but can also with many directions. Therefore, education must change. ${ }^{3}$

From the major complaint of the length of focus from youth nowadays to the consideration of technology and devices, creative thinking is one of the most important skill for teachers or lecturers. Creative thinking does help teacher to raise students awareness with openness and new way of teaching. Creative thinking also make education and the whole process of it more relevant than ever. So be it devices or even Google, with creative thinking teachers could surpass what Google and any other devices could not do, and one of them is making critical questions.

This article tries to explore the "creative" role of teachers, especially in responding the digital education. This article proposes rather than glorifying the benefits taken from technology, devices, and Google, teachers should be posited as the main and the most crucial factor in education and learning process. Yet, teacher should have philosophical foundation in teaching, because the vital proposition in teaching is making "rhetorical questions". Rhetorical questions could be a creative way to make 


\section{RESEARCH BACKGROUND}

John Dewey is one of the education experts who underlined the concepts of nature of teaching and teacher education. For Dewey, both are important elements both in the teaching process and in the learning process. Dewey emphasized that teachers must be typical and intensive. Teachers who have a typical and intensive learning process will make the focus and depth because of the depth of awareness in teaching and learning process. But the nature of such a teacher has prerequisites, that is someone who is able to open his mind to the world and have a clear director of himself. This prerequisite that according to Dewey became a kind of learning experience for teachers to be able to lead to a typical and intensive nature. This process was then by Dewey to become one of the postulates of teacher education. ${ }^{4}$

With the typical nature of teaching and incentives, Dewey would like to state that the learning process will change naturally. The learning process will also be a typical and intensive process. This learning process, according to Dewey, can provide superior communication and can adapt to the world. A typical process will provide students with the depth of understanding and detail of the knowledge provided by the learning process. During the learning process intensive knowledge will also be created so that the learning process really drills the psychology of the educational subjects in it to continue to learn and race against the world. This change in education naturally and gradually which then emphasizes the essence of the nature of teaching. ${ }^{5}$

Manuell Castells in his theory of network society argues that the world community is now fully connected. Microchip and the internet are protanogical actors in this regard. With the discovery of microchips and the internet, people in any part of the world are connected to each other, both through cable and through other telecommunications networks. Microchip and the internet are also the most instrumental actors in the advancement of world civilization through technology, information and communication. ${ }^{6}$ With the rapid distribution of information flow, now people and their environment are also required to be able to respond very quickly too. Likewise with education, or the education industry.

Being fully connected through the swift advances in technology, information flow, and rapid communication intensity, Indonesia's education industry is now facing new challenges. The new challenge is the improvement of human quality through existing educational institutions. As explained in the background of this article, the character of the current generation of students that is different from the generation that used to be a concern for teachers or educators who are in formal educational institutions. This of course relates to the networking community that has been argued by Castells. However, what keeps education and educational institutions going to survive is Dewey's concept of the nature of teaching and teacher education. Even we now are familiar with the word "googling" as a term refers to people who search and could find anything through Google search engine. 


\section{METHODOLOGY}

In this article, the data collection technique is using the study of literature or literature. This technique is also called the documentation technique. Data is using literature or literature from previous researches. Data collected through this literature study is secondary data, namely written data obtained from books, journals, articles and internet sites. ${ }^{7}$ Documentation technique is used considering the efficiency of the method. This research is not designed to be sophisticated work of scientific report or writing, but it is designed to be the initial writing on the contemporary assessment on Indonesian education system. Therefore, it does not need a lot of primary data in the form of actual numbers, observations, and indepth interviews. By making this paper as a starting point and initial assessment to see the current condition of the Indonesian education system, this paper seeks to open up new discourses about contemporary education.

Data collection through books, journals and articles is also called documentary data collection techniques. While data sources from the internet are allowed as long as the empirical responsibility is guaranteed. The choice of the internet as a medium to explore further information was also chosen with consideration of efficiency. Internet sources also provide examples of current and actual cases. Therefore, the contemporary education system that wants to be assessed here must also be presented with contemporary case examples.

In this article secondary data is also widely used. Secondary data is data collected through other available sources. ${ }^{8}$ Examples of secondary data include comments, interpretations or discussion of original material. Secondary data that is widely used in this article are discussions of original material. These discussions are important because they provide contemporary accents in the theoretical discussion. With this contemporary accentuation, theories that have actually been around for a long time can be used as a theoretical basis for contemporary cases, including the discussion of the present Indonesian education system and its relation to the world of communication, information and technology.

\section{RESULTS AND DISCUSSION}

Googling is an uptake terminology that is often used by people to refer to the mechanism of using the Google search engine. Google is not just a brand or name of a technology and information company. Now even Google has become a term and a verb. Because of this great influence, Google has become a magic word in the midst of society. Google has succeeded in changing people's habit patterns. Society is now more familiar and more daring to ask Google than to the people around it. Google's enormous influence has also affected the world of education in Indonesia.

In the world of Indonesian education, and for the current Indonesian education system, there are still some biases that occur. The education system in Indonesia has not been able to be fair to the object of education, namely students. The world of education in Indonesia often still features students who stand out academically in the classroom. This is often manifested through question and 
answer activities that exist in each of the activities of educational institutions. Then students will compete to give the correct answer. If students give wrong answers, it will result in lack of appreciation, or even a punishment. Then giving the correct answer psychologically overwhelms students, because of a desire for appreciation or even fear of punishment.

Google then becomes one of the alternative shortcuts to get appreciation or escape from fear of punishment. This is supported by the mainstreaming of information technology in the world of education which increasingly gives flexibility to students to access Google. So, often students use Google to answer questions in the learning process. Actually it does not need to be questioned, it's just that later symptoms appear that result in the dependence of students on Google, including complaints by teachers as written at the beginning of this article. Farther away, Google's role even exceeds the role of the teacher, because now many students are actually more trusting in Google than in the teacher. Google provides more detailed and complete information, and it doesn't stop at just one answer. Of course this is very different from most teachers in the world of education in Indonesia.

One role of creative thinking that is rooted in John Dewey's thoughts on education is creativity about reflective questions, or rhetorical questions. Rhetorical questions become important in the nature of teaching today. If in the all-connected network society Google is the most popular weapon that students often use to answer questions, then the creative question is what if a question cannot be answered by Google. Can teachers create questions that Google cannot answer? Of course you can, and questions like that are then called rhetorical questions. Rhetorical questions are certainly not just rhetoric, but must also show the reflective side of the essence being asked. Therefore, not only creative thinking is needed to make a rhetorical question, but also critical thinking.

Questions like, "what is meant by politics?" will be very easily answered by Google. Google will even provide many alternative answer links on the screen. So, teachers must be able to raise the level of questions, becoming like "why does Indonesia currently need good politics?". This question is actually a rhetorical question, but by giving more specifications to the question Google will find it difficult to find the answer. Because the Google search engine will only search through keyword equations, without searching for the meaning of what is in it. So if the logarithm of Google's engine runs only by relying on keywords, rhetorical questions become a counterweight to making Google irrelevant because rhetorical questions rely more on various versions of meaning.

In short, if Google provides students with multiple versions of answers, rhetorical questions can provide awareness of critical thinking and creative thinking, both for students and for teachers. So the rhetorical question is actually not only relevant in reflecting values in the world of education, but also in everyday life in network society. The writing team has used many versions of rhetorical questions for reflective activities in the learning process. So far rhetorical questions are the most effective method of making students focus on what is discussed in class. Thus, rhetorical questions can be one of the 
pedagogical mechanisms in improving students' cognition, affection, and psychomotor especially in thinking and acting in class.

\section{CONCLUSION}

In a network society, as stated by Manuel Castells, the connection between one person and another and between one community group and another is a necessity and will increase with the times. Google then became an integrated part in the world of education. Indeed technology and information do not always have a good effect if they are not used wisely. One of the bad impacts in the world of education is the high dependence by students on Google. However, as John Dewey had prescribed through the postulate of teacher education and the nature of teaching, teachers should be able to respond creatively and critically to this change. So, the main argument of this article is that rhetorical questions can be an alternative breaker of students' dependence on Google in the learning process. Rhetorical questions that are reflective and have various versions of meaning make it difficult to answer even through Google. Students must be able to digest the question and then give meaning to each answer that arises. This intensive and open-minded approach can later foster student enthusiasm for learning that previously depended on devices.

\section{BIODATA}

Dra. Herlina Suksmawati, M.Si is a lecturer of Communication Science Dept. on UPN "Veteran" Jawa Timur, Surabaya, Indonesia. She has a research interest in Marketing Communication and Consumer Behavior.

Praja Firdaus Nuryananda is a lecturer of International Relations Dept. on UPN "Veteran" Jawa Timur, Surabaya, Indonesia. He has a research interest in Globalization and Informational Society.

\section{REFERENCES}

\section{Books}

Bungin, B., 2007. Penelitian Kualitatif: Komunikasi, Ekonomi, Kebijakan Publik, dan Ilmu Sosial Lainnya. Jakarta: Kencana.

Castells, Manuel. 2010. The Rise of the Network Society. Wiley-Blackwell, West Sussex.

Greenwalt, Kyle. 2016. M. A. Peters (ed.). Encyclopedia of Educational Philosophy and Theory. Springer Science and Business Media Singapore.

Silalahi, Ulber. 2009. Metode Penelitian Sosial. Bandung: PT Refika Aditama.

\section{Electronic/Internet Sources}

Awaludin, Aziz. 2018. Teknologi (Bukan) Solusi Masalah Pendidikan. Available at: $\quad$ https://news.detik.com/kolom/d-4642405/teknologi-bukan-solusimasalah-pendidikan, accessed on $20^{\text {th }}$ February 2020. 
Susatyo, G. 2018. Masalah Siswa Sekolah di Era Digital. Available at: https://www.sahabatguru.com/2018/09/28/masalah-siswa-sekolah-di-eradigital/, accessed on $17^{\text {th }}$ February 2020.

Usman, Syaikhu. 2018. Sekolah masa depan di era digital-belajar dan mengajar di mana saja. Available at: http://theconversation.com/sekolah-masadepan-di-era-digital-belajar-dan-mengajar-di-mana-saja-95851, accessed on $20^{\text {th }}$ February 2020.

1 Susatyo, G. 2018. Masalah Siswa Sekolah di Era Digital. Available at: https://www.sahabatguru.com/2018/09/28/masalah-siswa-sekolah-di-era-digital/, accessed on $17^{\text {th }}$ February 2020.

${ }^{2}$ Usman, Syaikhu. 2018. Sekolah masa depan di era digital-belajar dan mengajar di mana saja. Available at: http://theconversation.com/sekolah-masa-depan-di-era-digital-belajar-dan-mengajardi-mana-saja-95851, accessed on $20^{\text {th }}$ February 2020.

3 Awaludin, Aziz. 2018. Teknologi (Bukan) Solusi Masalah Pendidikan. Available at: https://news.detik.com/kolom/d-4642405/teknologi-bukan-solusi-masalah-pendidikan, accessed on $20^{\text {th }}$ February 2020.

${ }^{4}$ Greenwalt, Kyle. 2016. M. A. Peters (ed.). Encyclopedia of Educational Philosophy and Theory. Springer Science and Business Media Singapore.

${ }^{5}$ Ibid.

${ }^{6}$ Castells, Manuel. 2010. The Rise of the Network Society. Wiley-Blackwell, West Sussex.

${ }^{7}$ Silalahi, Ulber. 2009. Metode Penelitian Sosial. Bandung: PT Refika Aditama.

${ }^{8}$ Bungin, B., 2007. Penelitian Kualitatif: Komunikasi, Ekonomi, Kebijakan Publik, dan Ilmu Sosial Lainnya. Jakarta: Kencana. 